\title{
Clinical and epidemiological profile of patients with hereditary angioedema treated in a referral outpatient clinic in Vitória, Espírito Santo - Brazil
}

\author{
Rafael Cicconi Arantes*, Débora Martins Ferreira, Murilo Andrade Santana, Faradiba Serpa, \\ Marina Moura Lopes Pereira, Therezinha Ribeiro Moyses, Fernanda Lugão Campinhos
}

From 3rd WAO International Scientific Conference (WISC) 2014

Rio de Janeiro, Brazil. 6-9 December 2014

\section{Background}

To assess epidemiological, social and clinical features of patients treated for hereditary angioedema in a referral outpatient clinic at Hospital Santa Casa de Misericordia de Vitoria, ES.

\section{Methods}

An observational, descriptive, cross-sectional study, based on a clinical-epidemiological survey of 51 patients with confirmed diagnosis of hereditary angioedema (HAE) from April 2011 to June 2014. Diagnostic confirmation was through the measurement of $\mathrm{C} 4$ and $\mathrm{C} 1$ inhibitor (C1-INH) quantitative and functional.

\section{Results}

Data from 51 patients, 29 (57\%) females and 22 (43\%) males, from 5 to 88 years old (mean: 32 years) was evaluated. Patients belonged to 7 families, 20 of them from the same family. The mean age of onset was 10 years and of diagnosis 26 years. Fifty (98\%) patients were symptomatic, and 28 (55\%) had experienced laryngeal edema. Deaths by laryngeal edema had occurred in 6 families. Crisis triggering factors were identified in $44(86 \%)$ patients. Forty-five (88\%) patients presented HAE due to quantitative deficit of $\mathrm{C} 1-\mathrm{INH}$. Maintenance treatment was required for 32 (63\%) patients, of whom 26 (81\%) used Danazol, 5 (16\%) Tranexamic acid, and 1 (3\%) both. Thirteen (28\%) patients needed icatibant to treat 23 crises.

\section{Conclusions}

The diagnosis of HAE is still late and deaths due to severe attacks continue to occur. Therefore, it is important that

Escola Superior De Ciências Da Santa Casa De Misericórdia De Vitória, Brazil health professionals are able to recognise and diagnose the disease and treat patients appropriately, as well as providing pharmacological services to control the disease.

Published: 8 April 2015

doi:10.1186/1939-4551-8-S1-A230

Cite this article as: Arantes et al:: Clinical and epidemiological profile of patients with hereditary angioedema treated in a referral outpatient clinic in Vitória, Espírito Santo - Brazil. World Allergy Organization Journal 2015 8(Suppl 1):A230.
Submit your next manuscript to BioMed Central and take full advantage of:

- Convenient online submission

- Thorough peer review

- No space constraints or color figure charges

- Immediate publication on acceptance

- Inclusion in PubMed, CAS, Scopus and Google Scholar

- Research which is freely available for redistribution
() Biomed Central 